\title{
Corrosion Inhibition of Copper and Its Alloys Using Benzotriazole
}

\author{
I. M. Ghayad and A.Y. Saad* \\ Chemistry Department, Faculty of Science, Kuwait University, \\ P.O. Box: 5969, Safat 13060, Kuwait and "Chemistry Department, \\ Faculty of Science, Jazan University, 140 Jazan, Saudia Arabia.
}

\begin{abstract}
7 HIS paper investigates the effect of benzotriazole (BTAH) on the corrosion of copper and two of its alloys namely; $\mathrm{Cu}-10 \mathrm{Ni}$ and $\mathrm{Cu}-$ $37 \mathrm{Zn}$ brass alloys in $3.5 \% \mathrm{NaCl}$ solution. Potentiodynamic polarization, potentiostatic polarization and electrochemical impedance spectroscopy (EIS) techniques were used in this investigation. Surface morphology was examined by using scanning electron microscopy (SEM). At lower concentration of BTAH $(0.001 \mathrm{M})$ copper and brass showed slightly better behavior than $\mathrm{CuNi}$ while at high concentration $(\geq 0.005 \mathrm{M})$ the $\mathrm{Cu}-10 \mathrm{Ni}$ alloy showed excellent inhibition efficiency compared to copper and brass. EIS showed that the polarization resistance, $R_{p}$, and hence the corrosion resistance is increased with the addition of $\mathrm{BTAH}$. Results are supported by surface investigations.
\end{abstract}

Keywords: Copper, Brass, Cu-Ni, Polarization, Corrosion, Inhibition, Benzotriazole and SEM.

Copper has its universal use in the electronic devices and many other applications. However, it easily reacts in ordinary oxygen-containing environments. The copper surface is covered with a layer consisting of a mixture of metallic copper, cuprous oxide and other corrosion products yielding a high electrical resistance. Benzotriazole (BTAH) is a well-known inhibitor of copper corrosion. It has been proved to be one of the most important inhibitors for copper and copper alloys corrosion over a wide temperature and $\mathrm{pH}$ range ${ }^{(1)}$.

Brass corrosion has been investigated in chloride solution ${ }^{(2-6)}$. Abd El Rehim et al. $^{(3)}$ have investigated electrochemical behavior of brass in aerated $\mathrm{NaCl}$ solution. The study results showed that at more negative potentials, $\mathrm{Zn}$ dissolution occurs while above a critical potential simultaneous dissolution of both copper and zinc occurs. Fenelon and $\operatorname{Breslin}^{(4)}$ have investigated electrochemical behavior of $\mathrm{Cu}, \mathrm{Cu}-37 \mathrm{Zn}$ and $\mathrm{Zn}$ in chloride solutions containing BTAH. They found that BTAH causes the increased resistance, the inhibition of $\mathrm{CuCl}_{2}$ formation as well as the formation of a product rich in $\mathrm{Zn}$. Quraishi et al. ${ }^{(5)}$ postulated $90-95 \%$ inhibiting efficiency of triazole on brass $70 / 30$ tested in $3 \% \mathrm{NaCl}$ solution. Martin et al. ${ }^{(6)}$ have investigated brass

*Corresponding author: e-mail: aya_saad70@yahoo.com 
dissolution in a $0.5 \mathrm{~mol} \mathrm{dm}{ }^{-3} \mathrm{NaCl}$ solution, clearly observing two separate regions, the first of which being unstable, obtained by dissolution of $\mathrm{Zn}$ and formation of vacancies, and the other a stable and rich copper surface.

$\mathrm{Cu}-\mathrm{Ni}$ alloys have tremendous applications in different industries, especially in ships, power stations, heat exchangers where chloride containing waters are always used. The understanding of the corrosion processes under the influence of chloride ions and the control of these processes were the subject worthy of intensive investigations ${ }^{(7-11)}$. In solutions with chloride concentration higher than $0.5 \mathrm{M}$ a relatively high nickel content is needed to combat the corrosion process and alloys with $>50 \% \mathrm{Ni}$ have shown corrosion currents compared to pure $\mathrm{Cu}^{(8,9)}$. The increase of $\mathrm{Ni}$ content is usually expensive and leads to the selective removal of $\mathrm{Ni}$, especially in chloride containing solutions ${ }^{(10,11)}$. The use of inhibitors seems to be the best way to overcome the corrosion problem of the $\mathrm{Cu}-\mathrm{Ni}$ alloys of low $\mathrm{Ni}$ contents.

Benzotriazole (BTAH) has long been known as an efficient inhibitor for the corrosion of copper and its alloys. Early studies suggested the cuprous oxide was essential for the forming the CuBTA film. Recent studies seem to disagree with this claim, since a CuBTA film also formed on the oxide-free copper surface $^{(12)}$.

Two mechanisms have been proposed to account for benzoriazole (BTAH) high inhibiting efficiency. The first attributes it to the adsorption of benzotriazole on the copper surface ${ }^{(13)}$ i.e.

$$
\mathrm{BTAH}_{(\mathrm{aq})}+\mathrm{Cu}=\mathrm{BTAH}: \mathrm{Cu}
$$

where BTAH:Cu refers to BTAH adsorbed on the copper surface. The second mechanism postulates the formation of a polymeric complex of $\mathrm{Cu}(\mathrm{I}) \mathrm{BTA}$,

$$
n \mathrm{Cu}^{+}+\mathrm{nBTAH}=[\mathrm{Cu}(\mathrm{I}) \mathrm{BTA}]_{\mathrm{n}}+\mathrm{nH}^{+}
$$

Youda et $a l .{ }^{(14)}$ have suggested that adsorption and complex formation are in equilibrium, i.e.

$$
\mathrm{nCu}+\mathrm{nBTAH}_{(\mathrm{ads})}=[\mathrm{Cu}(\mathrm{I}) \mathrm{BTA}]_{\mathrm{n}}+\mathrm{nH}^{+}+\mathrm{ne}
$$

Equation (3) reveals that increasing the $\mathrm{pH}$ value, the potential in the noble direction and the inhibitor concentration favor the formation of the protective polymeric film.

The present work represents a comparative study of the inhibition effect of benzotriazole on the copper, brass and copper nickel alloys. 


\section{Experimental}

Electrodes were prepared from $\mathrm{Cu}(99.9 \%)$, brass (Cu63 /Zn37) and $\mathrm{Cu} 90 / \mathrm{Ni10}$ as the testing specimens. The electrodes were in the form of rods having $0.96 \mathrm{~cm}$ diameter (i.e. $0.7234 \mathrm{~cm}^{2}$ cross sectional area). The immersed length of the rod was coated with a protective adhesive so that only the cross sectional area is exposed to the solution. Electrical contact to the external circuit is made through the rod. Electrodes were polished using $\mathrm{SiC}$ papers successively down to 2400 grits, followed by 0.3 micron alumina to acquire a mirror-like finish. A conventional three-electrode cell was used with an $\mathrm{Ag} / \mathrm{AgCl}$ reference electrode (0.197 V SHE) and a platinum counter electrode. Solutions were prepared using deionized water, BTAH from Aldrich, $\mathrm{NaCl}$ from Fluka. Potentiodynamic polarization curves were measured (at $5 \mathrm{mV} \mathrm{s}^{-1}$ ) in $3.5 \% \mathrm{NaCI}$ containing various concentrations of BTAH. The potential was controlled using a Gamry potentiostat. Potential scanning started from the less to the more noble potentials. Measurements were performed at $25 \pm{ }^{\circ} \mathrm{C}$ while the electrolyte was stirred using a magnetic stirrer. The electrodes were preirnmersed for $15 \mathrm{~min}$ in the chloride/BTAH solution before measuring the polarization curves. From the potentiodynamic curves, a certain potential was selected and specimens of the three tested alloys were polarized to this potential and kept at this potential for three hours. Specimens were then investigated under the scanning electron microscope (SEM). Electrochemical impedance spectroscopy (EIS) measurements were carried out under the open circuit potential within a frequency range of $100 \mathrm{kHz}$ to $0.01 \mathrm{~Hz}$ using a Gamry potentiostat with impedance software.

\section{Results and Discussion}

\section{Electrochemical measurements}

Figure 1 shows the potentiodynamic polarization curves of copper, brass and copper-nickel alloys in $3.5 \% \mathrm{NaCl}$. It is shown that brass and copper nickel alloys give nearly the same behavior and these alloys show a slightly better resistance than copper. This is evidenced by the shift of limiting current towards more noble values.

The effect of BTAH addition to the testing solution $(3.5 \% \mathrm{NaCl})$ on the polarization curves of copper, brass and copper-nickel alloys is illustrated in Fig. 2-4. In case of copper, the addition of BTAH results in a noticeable passive area compared to the blank solution $(3.5 \% \mathrm{NaCl})$. The passive area is shown to be small at $0.001 \mathrm{M} \mathrm{BTAH}(\sim 0.1 \mathrm{~V})$ and increases noticeably at 0.005 and $0.01 \mathrm{M}$ BTAH concentrations $(\sim 0.5 \mathrm{~V})$. At $0.01 \mathrm{M} \mathrm{BTAH}$, the passive region is sharper and slightly wider than 0.005 BTAH concentration. 


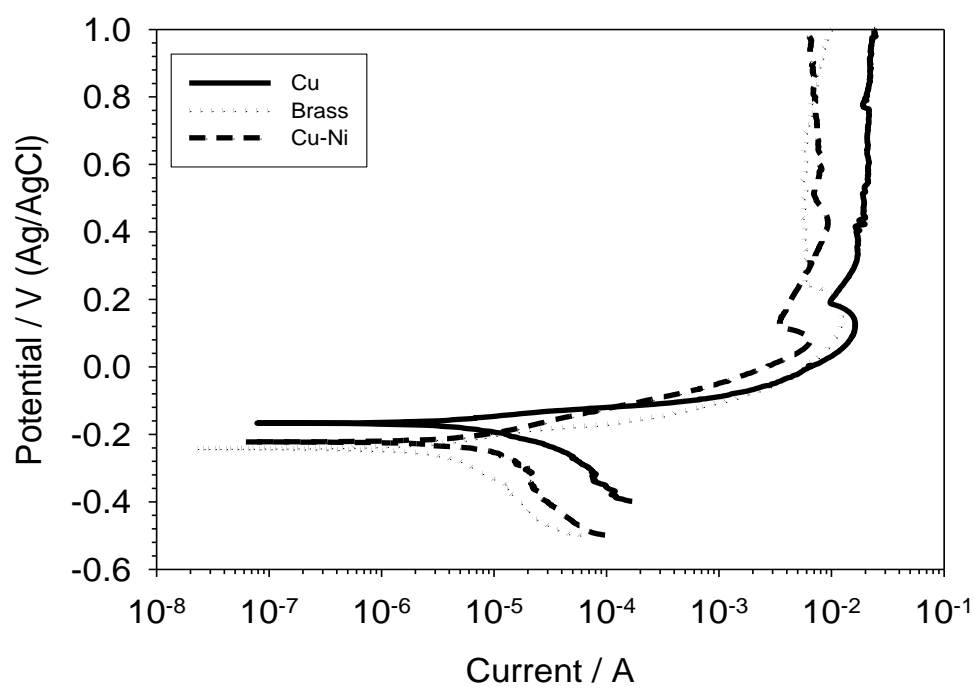

Fig. 1. Potentiodynamic curves of $\mathrm{Cu}$, brass and $\mathrm{Cu}-\mathrm{Ni}$ alloy in $3.5 \% \mathrm{NaCl}$.

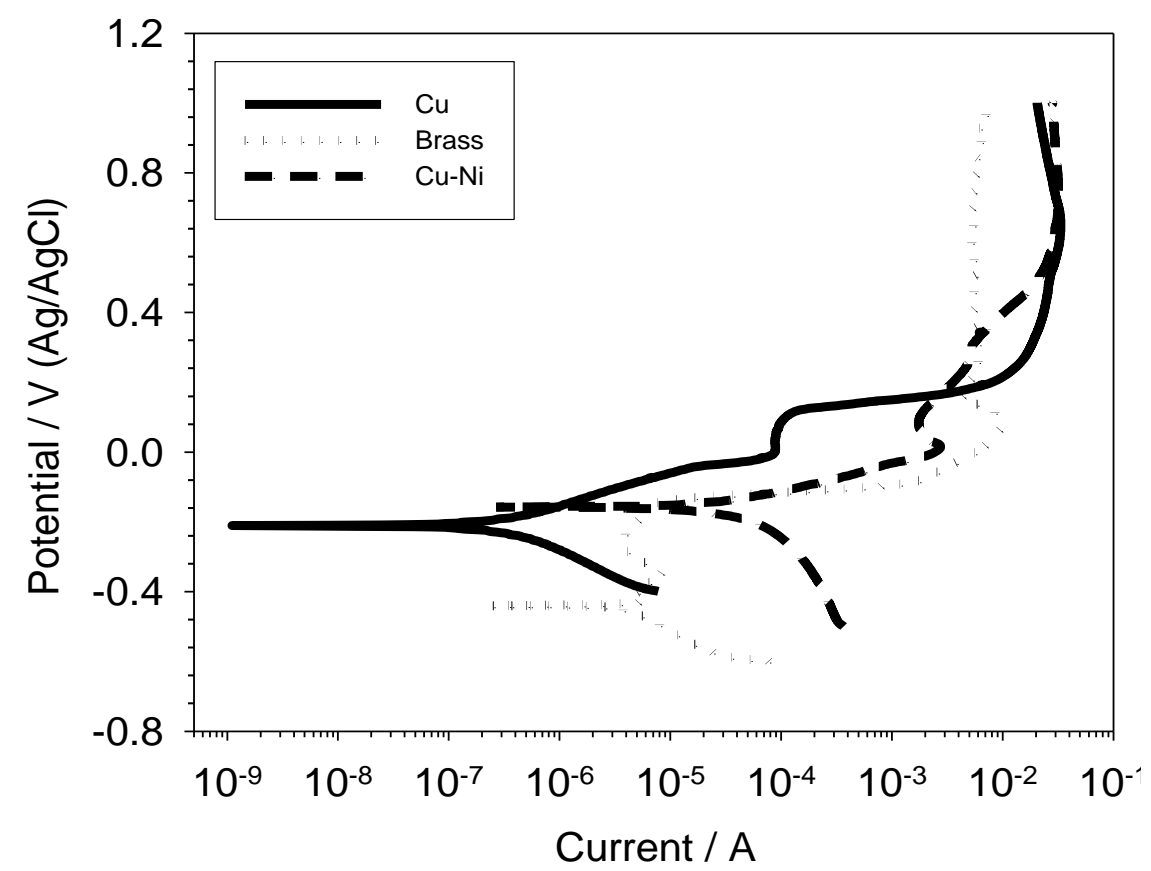

Fig. 2. Potentiodynamic curves of $\mathrm{Cu}$, brass and $\mathrm{Cu}-\mathrm{Ni}$ alloy in $3.5 \% \mathrm{NaCl}+0.001 \mathrm{M}$ BTAH.

Egypt. J. Chem. 53, No.3 (2010) 


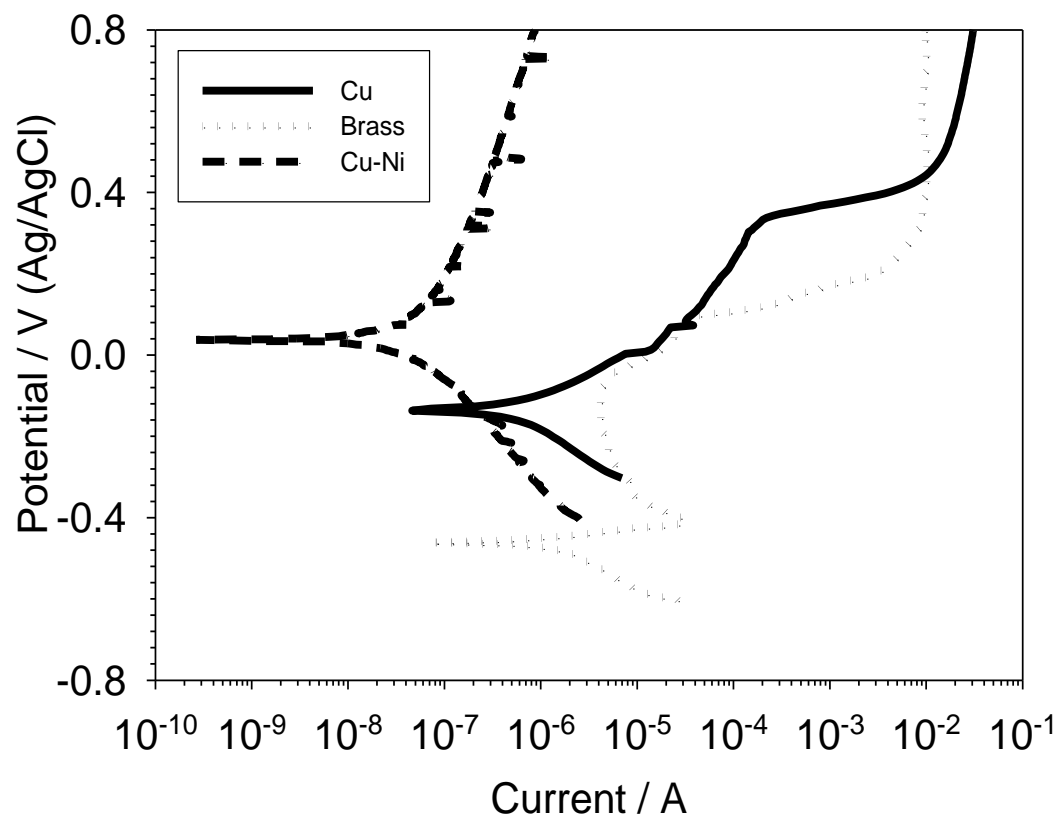

Fig. 3. Potentiodynamic curves of $\mathrm{Cu}$, brass and $\mathrm{Cu}-\mathrm{Ni}$ alloy in $3.5 \% \mathrm{NaCl}+0.005 \mathrm{M}$ BTAH.

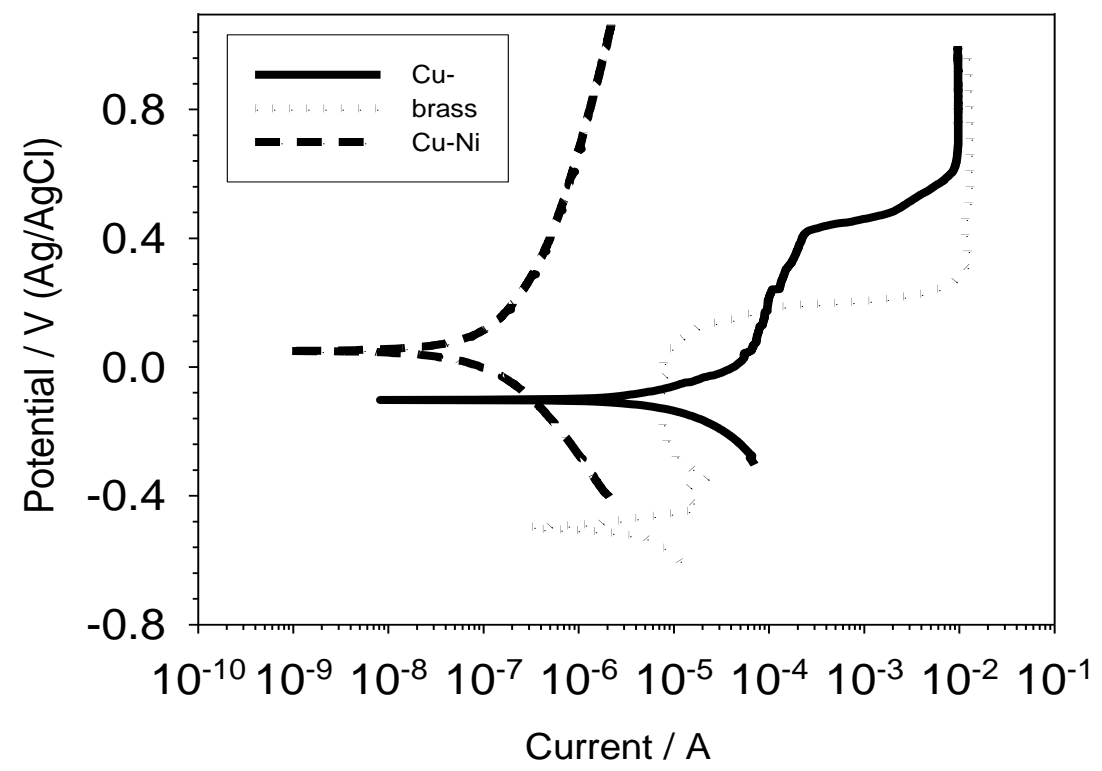

Fig. 4. Potentiodynamic curves of $\mathrm{Cu}$, brass and $\mathrm{Cu}-\mathrm{Ni}$ alloy in $3.5 \% \mathrm{NaCl}+0.01$ BTAH . 
In case of brass, the addition of BTAH results in the development of a passive region of about $0.3 \mathrm{~V}$ for $0.001 \mathrm{M}$ BTAH and $0.4 \mathrm{~V}$ for $0.005 \mathrm{BTAH}$ while $0.01 \mathrm{M}$ BTAH gives a $0.5 \mathrm{~V}$ passive region. It is also noted that, the addition of BTAH results in the shift of $\mathrm{E}_{\text {corr }}$ towards less noble values.

In case of copper-nickel, the addition of $0.001 \mathrm{M}$ BTAH has no effect on the potentiodynamic polarization behavior of the alloy. On the other hand, the addition of either 0.005 or $0.01 \mathrm{M}$ BTAH results in improving the corrosion behavior of the alloy to a very large extent. A quite large passive region is obtained $(\sim 2.0 \mathrm{~V})$ with a passivation current of $\sim 10^{-6} \mathrm{Acm}^{-2}$. $\mathrm{E}_{\text {corr }}$ values at both concentrations are shifted towards more noble values.

The potentiostatic polarization curves for the tested alloys which were obtained at $0.5 \mathrm{~V}$ vs $\mathrm{Ag} / \mathrm{AgCl}$ are shown in Fig. 5. In all cases the current starts at higher values and then decreases till it reaches a steady state value. The steady state current of the copper-nickel alloy shows the least value followed by that of copper and finally that of brass.

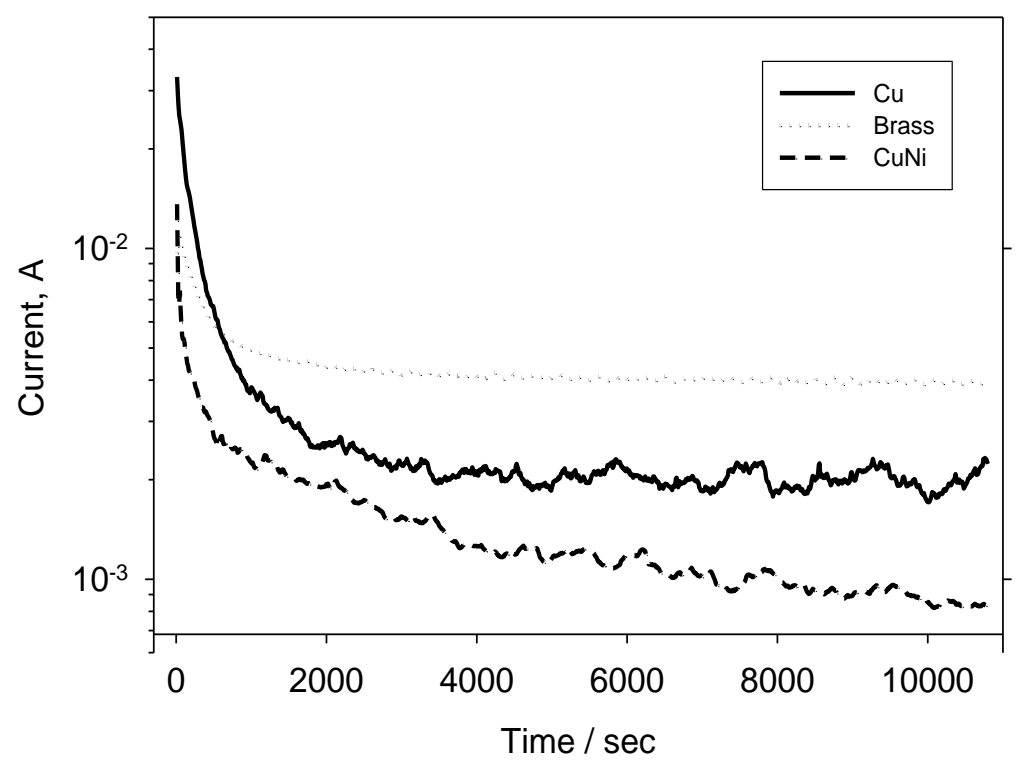

Fig. 5. Potentiostatic curves of tested alloys at $0.5 \mathrm{~V}(\mathrm{Ag} / \mathrm{AgCl})$ at room temperature for $3 \mathrm{hr}$ in $3.5 \% \mathrm{NaCl}+0.01 \mathrm{M} \mathrm{BTAH}$ and $25^{\circ} \mathrm{C}$.

Polarization resistance of copper, brass and copper-nickel alloys was determined in $3.5 \% \mathrm{NaCl}$ in the absence and in the presence of different concentrations of BTAH using electrochemical impedance spectroscopy (EIS) technique. Figure 6 illustrates the Bode plot of EIS results. The polarization resistance $\left(R_{p}\right)$, in some instances called the charge transfer resistance $\left(R_{c t}\right)$, can Egypt. J. Chem. 53, No.3 (2010) 
be calculated by subtracting the impedance at the low frequency which represents the solution resistance $\left(\mathrm{R}_{\mathrm{s}}\right)$ from the impedance at the high frequency which represents the $R_{p}+R_{s}^{(15)}$. This also can be done using the instrument software by fitting the data to a model or equivalent circuit predetermined in the software. The simplest form of this equivalent circuit is obtained when the impedance of the interface is caused primarily by the charge-transfer step, in which case $Z=R_{p}$ where $R_{p}$ is the polarization (or charge-transfer) resistance of the interface (included in Fig. 6b). Table 1 lists these values. The polarization resistance is inversely proportional to the corrosion current, $\mathrm{i}_{\text {corr, }}$ i.e.

$$
R_{p}=\frac{b_{a} b_{c}}{2.3\left(b_{a}+b_{c}\right) i_{\text {corr }}}
$$

where $b_{a}$ and $b_{c}$ are the cathodic and anodic Tafel slopes. Equation 4 denotes that there is a direct proportionality between $R_{p}$ and corrosion resistance. Table 1 shows that the presence of BTAH leads to the increase of $R_{p}$ for the tested alloys. However; the response differs from one alloy to another. The largest increase in $\mathrm{R}_{\mathrm{p}}$ is exhibited by the $\mathrm{CuNi}$ alloy at 0.005 and $0.01 \mathrm{M}$ BTAH which give $1.37 \times 10^{5}$ and $1.87 \times 10^{5}$ for $0.005 \mathrm{M}$ and $0.01 \mathrm{M}$ BTAH, respectively. On the other hand, copper exhibited slightly higher values of $R_{p}$ than brass. $R_{p}$ values of $2.5 \times 10^{4}$ and $1.8 \times 10^{4} \mathrm{ohm}$ are obtained for copper and brass, respectively in the presence of $0.01 \mathrm{M}$ BTAH. These values are quite low in comparison to the value of $R_{p}$ obtained for copper-nickel alloy $\left(1.87 \times 10^{5}\right)$. Results of polarization resistance measurements supports those of potentiodynamic and potentiostatic measurements in assigning the highest inhibition efficiency for the BTAH film formed on the surface of Cu90Ni10 alloy.

TABLE 1. Effect of the concentrations of BTAH on the polarization resistance $\left(\mathbf{R}_{p}\right)$, $\left(\mathrm{ohm} . \mathrm{cm}^{2}\right)$, of the metal/electrolyte interfaces of different alloys in $3.5 \%$ NaCl.

\begin{tabular}{|c|c|c|c|c|}
\hline Alloy $R_{p}$ & $3.5 \% \mathrm{NaCl}$ & $\begin{array}{c}3.5 \% \mathrm{NaCl}+ \\
\text { 0.001MBTAH }\end{array}$ & $\begin{array}{c}3.5 \% \mathrm{NaCl}+ \\
0.005 \mathrm{M} \text { BTAH }\end{array}$ & $\begin{array}{c}\text { 3.5\% NaCl + } \\
\text { 0.01 M BTAH }\end{array}$ \\
\hline Copper & $4.48 \times 10^{3}$ & $2.2 \times 10^{4}$ & $5.7 \times 10^{4}$ & $2.5 \times 10^{4}$ \\
\hline Brass & $4.27 \times 10^{3}$ & $1.9 \times 10^{4}$ & $1.2 \times 10^{4}$ & $1.8 \times 10^{4}$ \\
\hline $\mathrm{Cu} / \mathrm{Ni}$ & $4.95 \times 10^{3}$ & $3.1 \times 10^{4}$ & $1.37 \times 10^{5}$ & $1.87 \times 10^{5}$ \\
\hline
\end{tabular}



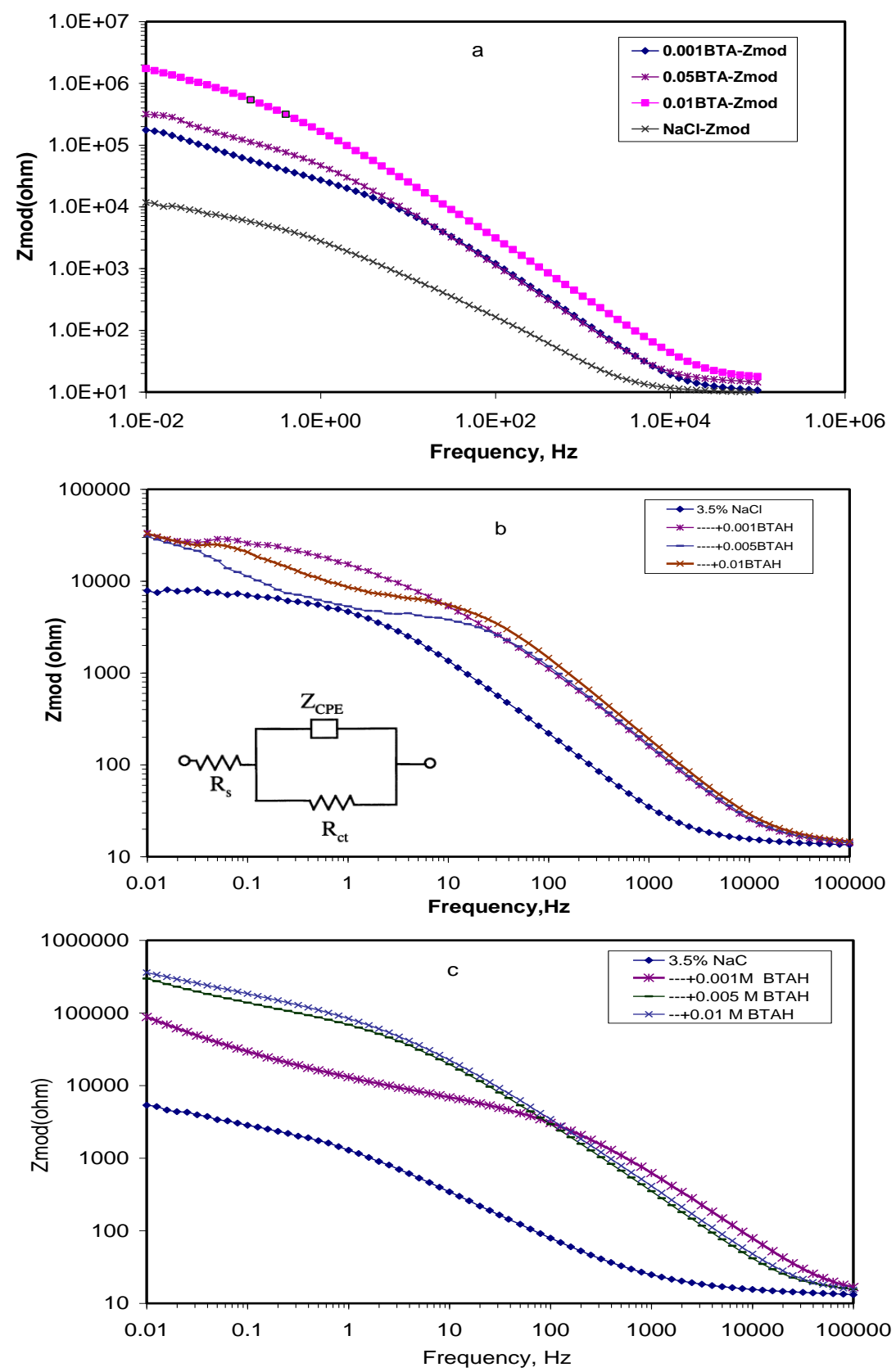

Fig.6. Effect of benzotriazole concentration on the impedance of copper (a), brass $(37 \% \mathrm{Zn})(\mathrm{b})$ and $\mathrm{Cu} 90 \mathrm{Ni} 10$ (c) in $3.5 \% \mathrm{NaCl}$ at $25^{\circ} \mathrm{C}$.

Egypt. J. Chem. 53, No.3 (2010) 


\section{Surface characterization}

SEM micrographs of copper, brass and $\mathrm{Cu}-\mathrm{Ni}$ alloys are shown in Fig. 7-8. Micrographs show that the specimen surface morphology in presence and in absence of BTAH. Specimens left for $3 \mathrm{hr}$ at the open circuit potential (blank specimens) do not show any appreciable corrosion attack for copper, brass and copper-nickel (Fig. 7). SEM micrographs of specimens hold for $3 \mathrm{hr}$ at $0.5 \mathrm{~V}$ $(\mathrm{Ag} / \mathrm{AgCl})$ in $3.5 \% \mathrm{NaCl}+0.01 \mathrm{M} \mathrm{BTAH}$ (Fig. 8) clarify that copper suffers from corrosion attack in the form of pits. Brass still subjected to corrosion attack but to a lower extent than copper. Corrosion attack takes the form of pits lower in size compared to those of copper and also etching of the surface are noticed. On the other hand, copper-nickel does not suffer little corrosion attack in the form of mild etching.

The present work denotes an excellent corrosion inhibition of $\mathrm{CuNi}$ alloy compared to $\mathrm{Cu}$ and brass at sufficiently high concentration of BTAH $(\geq 0.005$ $\mathrm{M})$. It also denotes a slightly better BTAH inhibition for $\mathrm{Cu}$ than brass. All these observations can be understood if we look at the nature of the protective film formed on the surface of these alloys. It is well known that the resistance to $3.5 \% \mathrm{NaCl}$ corrosion of copper and its alloys is related to the formation of a thin, adherent, protective surface film of cuprous oxide ${ }^{(16)}$. However, the formed film differs from one alloy to another. For brass, the film contains $\mathrm{ZnO}$ in addition to the main constituent of $\mathrm{Cu}_{2} \mathrm{O}^{(17-19)}$. For copper-nickel alloys, nickel is incorporated in the $\mathrm{Cu}_{2} \mathrm{O}$ film improving its characters and consequently results in the formation of a more protective copper benzotriazole film upon its presence in solution. It was also noted the shift of $\mathrm{E}_{\text {corr }}$ of brass towards more negative values in the presence of BTAH. This can be related to the fact that $\mathrm{Zn}$ in brass is less noble than $\mathrm{Cu}^{(20)}$.

\section{Conclusions}

Copper, brass $(37 \mathrm{Zn})$ and $\mathrm{Cu} 90 \mathrm{Ni10}$ alloys were tested in $3.5 \% \mathrm{NaCl}$ solution in the absence and in the presence of different concnetartions of BTAH. At sufficiently high concentration $(\geq 0.005 \mathrm{M})$ of BTAH the $\mathrm{Cu}-10 \mathrm{Ni}$ alloy showed excellent inhibition compared to copper and brass. EIS showed that the polarization resistance, $R_{p}$, and hence the corrosion resistance is increased with the increase of the concentration of BTAH. The excellent inhibition shown by $\mathrm{Cu} 90 \mathrm{Ni} 10$ can be related to the incorporation of nickel in the oxide film formed on the alloy surface improving its characteristics which in turn results in the formation of a highly protective copper benzotriazole film upon its presence in solution.

Acknowledgements : The authors acknowledge the support of this work by the Research Administration of Kuwait University. They also acknowledge the use of the scanning electron microscope (SEM). 

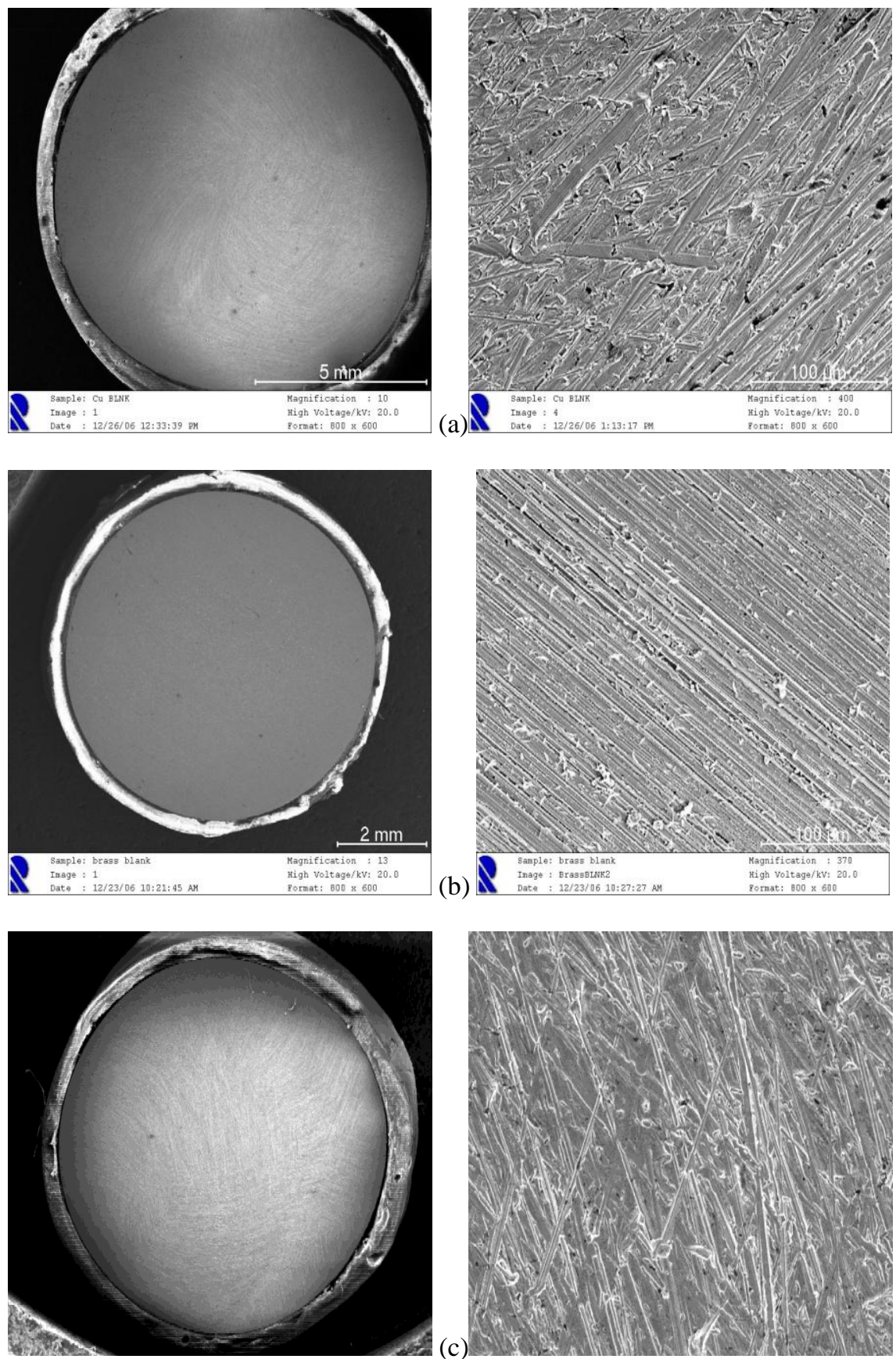

Fig. 7. SEM micrographs of copper (a), brass (b) and $\mathrm{Cu} / \mathrm{Ni}$ (c) samples after $3 \mathrm{hr}$ immersion at open circuit potential in $3.5 \% \mathrm{NaCl}$ at $25^{\circ} \mathrm{C}$.

Egypt. J. Chem. 53, No.3 (2010) 


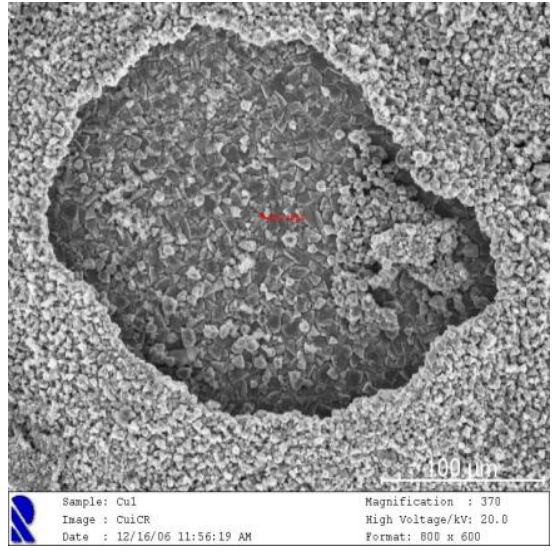

(a)

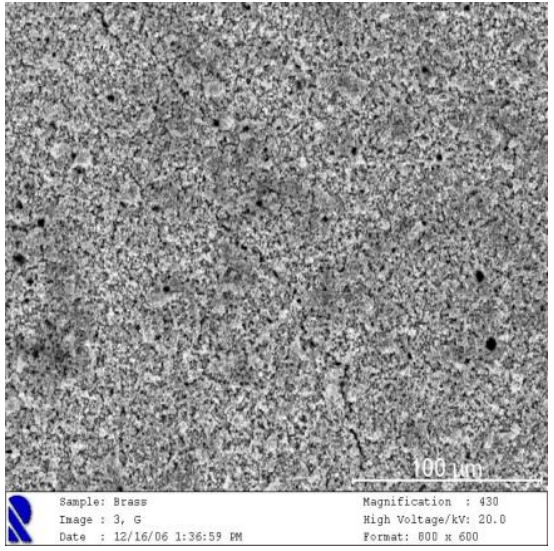

(b)

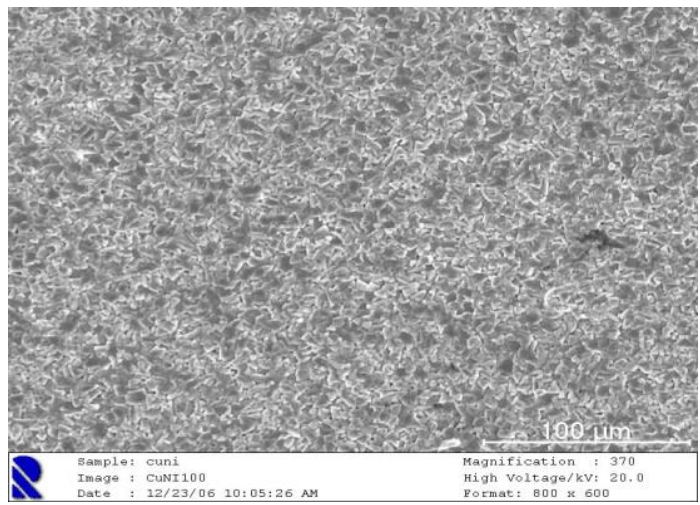

(c)

Fig. 8. SEM micrographs of copper (a), brass (b) and CuNi (c) samples after 3 hr potentiostatic experiment at $0.5 \mathrm{~V}(\mathrm{Ag} / \mathrm{AgCl})$ in $3.5 \% \mathrm{NaCl}+0.01 \mathrm{M}$ BTAH and $25^{\circ} \mathrm{C}$.

\section{References}

1. Bellakhal, N. and Dachraoui, M., Mat. Chem. Phys., 85, 366 (2004).

2. Antonijevi'c, M.M., Mili'c, S.M., Serbula, S.M. and Bogdanovi'c, G.D., Electrochimica Acta, 50, 3693 (2005).

3. Abd El Rehim, S.S., Assaf El-Saued, F.H., Zaky, A., Br. Corros. J., 30 (4), 297 (1995).

4. Fenelon, A.M. and Breslin, C.B., J. Appl. Electrochem., 31 (5) 509 (2001).

5. Quraishi, M.A., Farooqi, I.H. and Saini, P.A., Br. Corros. J., 35 (1) 78 (2000). 
6. Martin, H., Carro, P., Hernandez, C.A., Morales, J., Fernandez, G., Esparza, P., Gonzalez, S., Salvarezza, R.C., Arvia, A.J., J. Phys. Chem. B, 104 (34) 8229 (2000).

7. Badawy, W.A., Ismail, K.M. and Fathi; Electrochim, A.M., Acta, 51, 4182 (2006).

8. Milosev, I. and Metikos-Hukovic, M., Electrochim, Acta, 42, 1537 (1997).

9. Kamkin, A.N., Davydov, A.D., Zhou, G.D. and Marichev, V.A., Russ. J. Electrochem., 35, 531 (1999).

10. Blundy, R.G. and Pryor, M.J., Corros. Sci., 12, 65 (1972).

11. Badawy, W.A., Ismail, K.M. and Fathi, A.M., Electrochim. Acta, 50, 3603 (2005).

12. Da-quan Zhang, Li-xin Gao, Guo-ding Zhou; Appl. Surf. Sci., 252, 4975 (2006).

13. Allam, N.K., Ashour, E.A., Hegazy, H.S., El-Anadouli, B.E., Ateya, B.G., Scr. Mater., 54, 1673 (2006).

14. Youda, H. Nishihara and Aramaki, K. , Electrochem. Acta, 35, 1011 (1990).

15. Gao, G. and Liang, C.H., Corros. Sci., 49, 3479 (2007).

16. Kear, G., Barker, B. D. and Walsh , F.C., Corros. Sci., 46, 109 (2004).

17. Abouswa, K., Elshawesh, F., Elragei, O. and Elhood, A., Desalin., 205, 140 (2007).

18. Antonijevic', M.M., Milic', S.M. and Petrovic, M.B., Corros. Sci., 51, 1228 (2009).

19. Xiao-Zhong Zhou, Chu-Ping Deng, Yu-Chang Su; J. Alloys Compd., 491, 92 (2010).

20. Mamas, S., Kıyak, T., Kabasakaloglu, M. and Koc, A., Mater. Chem. Phys. 93, 41 (2005). 


\section{تثبيط التآكل للنحساس وسبائكه بإسـتخدام البنزوتراي أزول كمثبط}

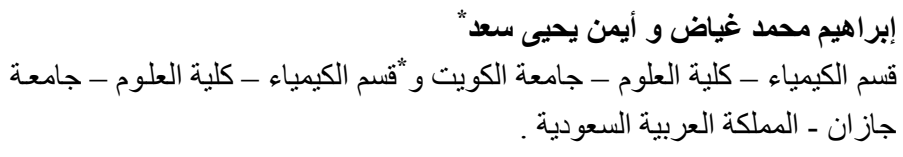

\footnotetext{
هــا البحث يدرس تأثيــر البنزوتــراى أزول (BTAH) على تثبيط تآكل النحساس

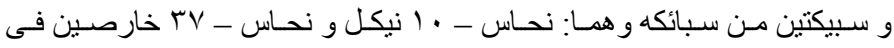

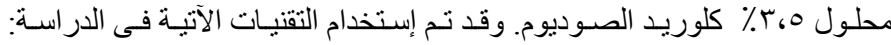

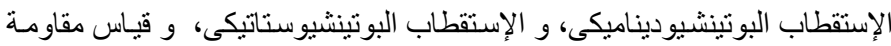

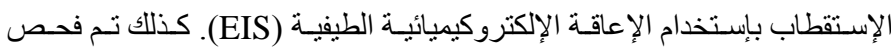

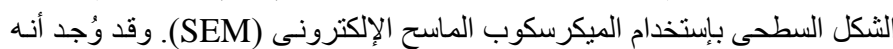

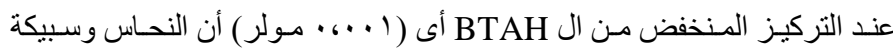

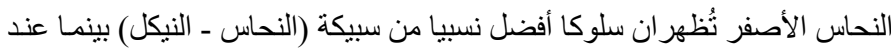

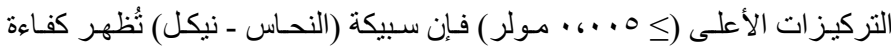

تثيط ممتازة بالمقارنة بالنحاس وسبيكة النحاس الأصفر. لتهر

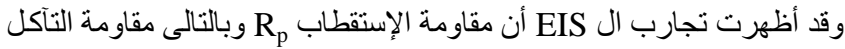

تزداد بزيادة تركيز البنزوتراى أزول. وقد دُعمت النتائج بقياسات فحص النقاب السطح.
} 